\title{
Spawning stock dynamics of two penaeid prawns, Metapenaeus bennettae and Penaeus esculentus, in Moreton Bay, Queensland, Australia
}

\author{
A. J. Courtney*, J. M. Masel \\ Queensland Department of Primary Industries, Southern Fisheries Centre, Deception Bay, 4508 Queensland, Australia
}

\begin{abstract}
Spawning stock dynamics of 2 commercially important penaeid prawns, Metapenaeus bennettae and Penaeus esculentus, from 9 stations in Moreton Bay (27. $15^{\prime} \mathrm{S}, 153^{\circ} 15^{\prime} \mathrm{E}$ ), southeast Queensland, Australia, were examined. An egg production index (EPI), based on the relative abundance, proportion that were mature or ripe, and size of adult females, was used as a measure of egg production in the 2 populations. Egg production by $M$. bennettae was 20 to 30 higher than that by $P$. esculentus, extended over 7 to 8 mo each year and peaked from February to March (late summer to early autumn). Monthly patterns in egg production by $M$. bennettae varied between years. In contrast, $P$ esculentus produced most of its eggs in a single, clearly defined peak in October (spring), although production continued to March (early autumn) each year The seasonal onset and subsequent decline in maturation in $P$. esculentus were rapid. Egg production by $M$. benneltae was several times higher at the 5 northern stations than at the 4 southern stations and negatively correlated with salinity during the main spawning period. Egg production by $P$. esculentus was less varied among stations and positively correlated with depth. $P$. esculentus appeared more likely than $M$. bennettae to experience recruitment overfishing because (1) the peak spawning period for $P$. esculentus was dependent on relatively few adult females spawning over a short period, and (2) the selectivity of trawl nets used in the bay was much higher for $P$. esculentus spawners than for those of $M$. bennettae. Compared with more northern populations, $P$. esculentus in Moreton Bay matured at a larger size, had lower incidences of insemination and mature or ripe females, and had a shorter spawning period. These results suggest the likelihood of recruitment overfishing in $P$. esculentus increases with increasing latitude.
\end{abstract}

KEY WORDS: Egg production index · Spawning stock - Penaeid prawn - Recrultment overfishing

\section{INTRODUCTION}

The likelihood of recruitment overfishing in penaeid fisheries has generally been considered to be low because of the high fecundity of the prawns and because fishing spawning stocks below levels required to maintain recruitment was considered unprofitable (Neal 1975). Garcia (1983) reviewed the literature on penaeid spawning stock-recruitment relationships and concluded there was no evidence to demonstrate that

\footnotetext{
- Present address: University of British Columbia, Fisheries Centre, 2204 Main Mall, Vancouver, British Columbia Canada V6T 124. E-mail: tonyc@fısheries.com
}

numbers of recruits were a function of spawning stock size. Since then, however, Penn \& Caputi $(1985,1986)$, Penn et al. (1995) and Gracia (1991, 1996) have shown that penaeid prawn fisheries can experience recruitment overfishing. These later studies highlight the importance of understanding the temporal and spatial components of egg production in penaeid fisheries in order to monitor the level of fishing effort directed at spawning stocks and to reduce the effects of recruitment overfishing when it occurs

In Moreton Bay (27० $\left.15^{\prime} \mathrm{S}\right)$ on the southeast Queensland (Australia) coast, the penaeid fauna is diverse and forms the basis of a trawl fishery that has been operating since the early 1950s (Ruello 1975a). Hyland (1987) 
identified 12 penaeid species in the bay, 3 of which (Metapenaeus bennettae, Penaeus plebejus and $P$. esculentus comprise the bulk of the catch. Data from a compulsory logbook programme indicate an average of $571( \pm 92 \mathrm{SE}) \mathrm{t}$ of prawns are trawled from Moreton Bay annually (based on landings 1989-94, inclusive). Management of the fishery includes limits on the number and size of vessels, a maximal trawl head rope length, minimal and maximal mesh sizes, and spatial and weekend closures.

The biology of the 3 principle species, and their contribution to the bay's total annual landings, differ Metapenaeus bennettae is a small species endemic to the central and southern coastal waters of eastern Australia (Grey et al. 1983). Although it constitutes 40 to $50 \%$ of the bay's total prawn landings, the population dynamics of $M$. bennettae have received little research attention. Morris \& Bennett (1952), Dall (1958), Young \& Carpenter (1977) and Hyland (1987) have shown that it typically inhabits rivers or shallow $(<20 \mathrm{~m})$ coastal waters and is capable of spawning in periodically enclosed coastal lakes. Penaeus plebejus is also endemic to the central and southern coastal waters of eastern Australia. It comprises 30 to $40 \%$ of the bay's total prawn landings and differs from $M$. bennettae in that it is more oceanic and migratory. P. plebejus utilise the bay as post-larvae and juveniles for only a few weeks (Lucas 1974) before migrating to deeper, oceanic waters to reproduce (Potter 1975, Ruello 1975b, Glaister et al. 1987, Montgomery 1990, Courtney et al. 1995b). Annual landings and value of $P$. plebejus increase outside Moreton Bay where it supports a large, monospecific fishery. Its population dynamics have received considerable research attention (Lucas 1974, Glaister et al. 1987, 1990, Gordon et al, 1995). P. esculentus is endemic to Australia's tropical and subtropical coastal waters (Grey et al. 1983). Although of major commercial importance nationally (Dall 1985), $P$. esculentus constitutes only 10 to $15 \%$ of the total prawn catch in Moreton Bay. Its population dynamics have been studied intensively in Torres Strait, northeastern Australia (Mellors 1990), the Gulf of Carpentaria, northern Australia (Kirkwood \& Somers 1984, Crocos 1987b, Loneragan et al. 1994) and Exmouth Gulf, Western Australia (Penn \& Caputi 1985, 1986, Penn et al. 1995). Post-larvae and juveniles prefer shallow seagrass habitats (Young \& Carpenter 1977. Staples et al. 1985, Coles et al. 1987, O'Brien 1994). P. esculentus in Moreton Bay does not appear to undertake significant migrations and most likely matures and spawns in the bay.

The objective of this paper is to describe and compare the spawning stock dynamics of Metapenaeus bennettae and Penaeus esculentus in Moreton Bay to obtain a better understanding of their population dynamics and to reduce the risk of recruitment overfishing. The study is particularly relevant to $P$. esculentus because this species appears vulnerable to recruitment overfishing. In Exmouth Gulf (Penn et al. 1989) and the Gulf of Carpentaria (Crocos 1991) management measures have been introduced to limit fishing effort directed at $P$. esculentus spawning stocks. Currently, there is no control over the level of fishing effort directed at any penaeid spawning stock on Australia's eastern seaboard. The study also facilitates a comparison of the spawning stock dynamics of $P$. esculentus to be made between tropical and sub-tropical populations because Moreton Bay approximates the southern limit of fishing for this species. The significance of latitudinal distribution of the spawning stock is discussed in relation to the probability of recruitment overfishing occurring

\section{MATERIALS AND METHODS}

A research trawler fitted with 2 otter-board trawl nets was used to sample prawn populations from 9 stations in Moreton Bay (Fig 1) between August 1988 and July 1990. Each station was sampled once at night for 30 min (bottom time) on, or as close as possible to, the new moon of each lunar month. After each trawl, all

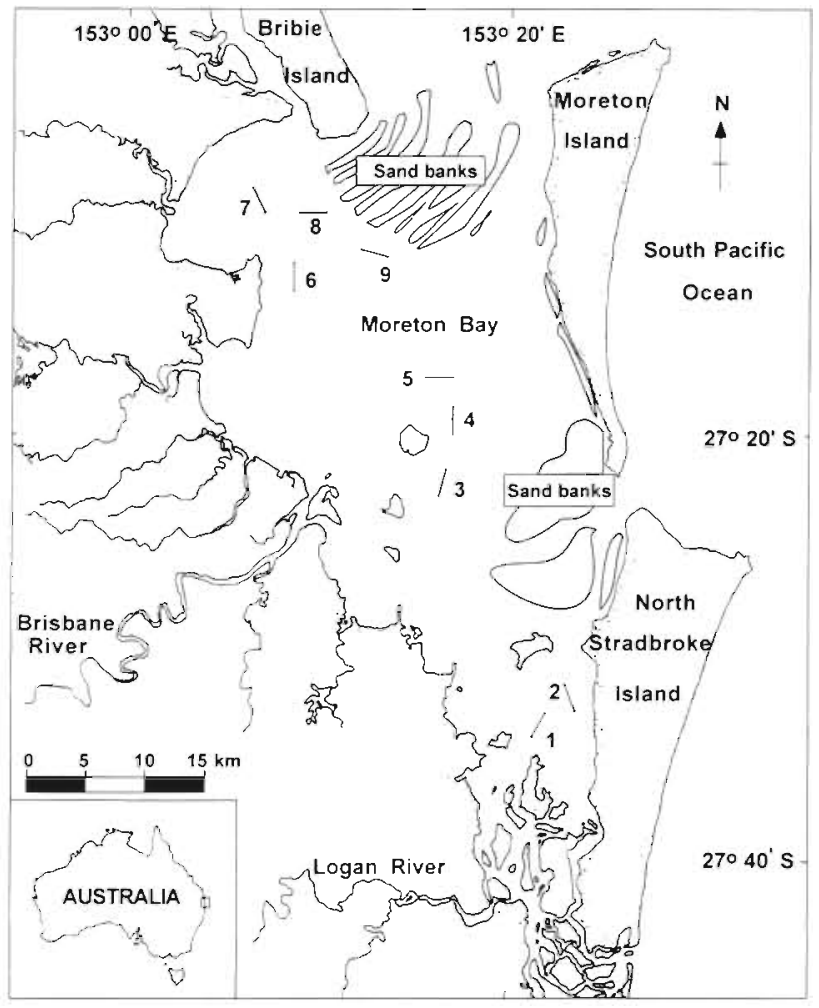

Fig. 1 Map of Moreton Bay on the southeast Queensland (Australia) coast showing the position and orientation of the 9 sampling stations 
prawns from each net were placed into labelled bags and frozen. Depth, bottom temperature and salinity were measured at each station on each lunar month to examine possible correlations between abiotic factors and spawning activity. Further details of the field sampling methods have been described in Courtney et al (1995a)

All prawns were sorted to species, sexed and their carapace length (CL) measured to the nearest $\mathrm{mm}$. Reproductive information was obtained from a total of 40 females of each species from each station randomly selected from both nets. Where fewer than 40 females were available, all females of that species were examined. Presence or absence of a spermatophore was determined by examining the thelycal cavity. Ovarian tissue was dissected from the first abdominal somite of each female and examined histologically. Maturation. based on descriptions by Tuma (1967) and Yano (1988). was recorded for each female.

Crocos (1991) noted that most reproductive studies of penaeid prawn populations have relied upon female ovarian condition and have been based upon single variables, such as gonado-somatic indices $\left(\mathrm{O}^{\prime} \mathrm{Connor}\right.$ 1979, Anderson et al. 1985, Potter et al. 1989) or the proportion of females classed as mature or ripe (Shlagman et al. 1986, El Hady et al. 1990, Gab-Alla et al. 1990, Potter et al. 1991). A more quantitative measure of egg production in a population should also consider the abundance and size of the adult females. For this reason, an index similar to that described by Crocos (1991) was used in the present study. The egg production index, EPI, for a particular sampling station and sampling time, is expressed thus:

$$
\mathrm{EPI}=\operatorname{ap}\left[\frac{\sum_{j=1}^{n} \int C L_{j}}{n}\right]
$$

where $a$ is total number of adult females in the sample; $p$ is the proportion of adult females classed as spawners (histologically mature or ripe) $; j=$ the $j$ th spawner; $\int C L$, is an estimate of ovary weight in the $j$ th spawner, based on a carapace length-ovary weight relationship; and $n$ is the number of spawners. Since fecundity is considered to be directly proportional to the weight of the ovary in mature or ripe females (Dall et al. 1990a). estimates of ovary weight were used as a proxy measure of fecundity. Data used to estimate carapace length-ovary weight relationships were derived by removing and weighing ovaries from approximately every second female examined in the second year of the study. Only data from mature or ripe females were included in the final regressions.

Analysis of variance (ANOVA) was used to determine if egg production varied significantly between stations, lunar months and years. EPIs were transformed $\left[\log _{e}(E P I+1)\right]$ prior to ANOVA. Lunar months do not occur at the same calendar-time each year. Therefore, in order to balance the ANOVA, 12 lunar months were identified for each year of the study. In the first year, the first lunar monthly sample corresponded to sampling trip 1 (mid August 1988) and the 12th to sampling trip 12 (late June 1989). In the second year, the first lunar monthly sample corresponded to trip 13 (late July-early August 1989) and the 12th to trip 24 (late June 1990). Pearson correlation coefficients were used to examine relationships between EPIs and water temperature, salinity and depth.

\section{RESULTS}

Of the 25 lunar monthly sampling trips, 24 were successfully completed. One trip (4 June 1989) was abandoned due to mechanical failure of the vessel. A total of 42038 female Metapenaeus bennettae and 2830 female Penaeus esculentus were sampled. Of these, reproductive information was obtained on $3475 \mathrm{M}$ bennettae and 1607 P. esculentus.

\section{Maturation}

None of the 14 female Metapenaeus bennettae smaller than $14 \mathrm{~mm} \mathrm{CL}$ was found with vitellogenic (mature or ripe) ovaries (Fig. 2a). The incidence of vitellogenesis increased markedly with size from $9 \%$ at $14 \mathrm{~mm} \mathrm{CL}$ to a maximum of $52 \%$ at $25 \mathrm{~mm} \mathrm{CL}$. Trends in size classes larger than $27 \mathrm{~mm} \mathrm{CL}$ were less reliable due to low abundance of large individuals. The minimum size at which vitellogenesis occurred in Penaeus esculentus was $30 \mathrm{~mm} \mathrm{CL} \mathrm{(Fig} \mathrm{2a).} \mathrm{The} \mathrm{inci-}$ dence increased comparatively slowly with size from $<1 \%$ at $30 \mathrm{~mm} \mathrm{CL}$ to a maximum of $43 \%$ at $44 \mathrm{~mm} \mathrm{CL}$. About $20 \%$ of female $P$. esculentus larger than $40 \mathrm{~mm}$ CL possessed vitellogenic ovaries.

Adult females were defined as those equal to, or larger than, the smallest size at which vitellogenesis occurred. Thus, females were classed as adult if they were $\geq 14 \mathrm{~mm}$ CL for Metapenaeus bennettae or $\geq 30 \mathrm{~mm}$ CL for Penaeus esculentus. The overall incidence of vitellogenic adult females was 36.5 and $9.4 \%$ for $M$. bennettae and $P$. esculentus, respectively. Carapace length-ovary weight relationships for females classed as mature or ripe (Fig. 2b) were expressed as:

$$
Y=a X b
$$

where $Y$ is ovary weight $(g) ; X$ is carapace length $(\mathrm{mm}) ;$ and $a$ and $b$ are coefficients. Regression para- 

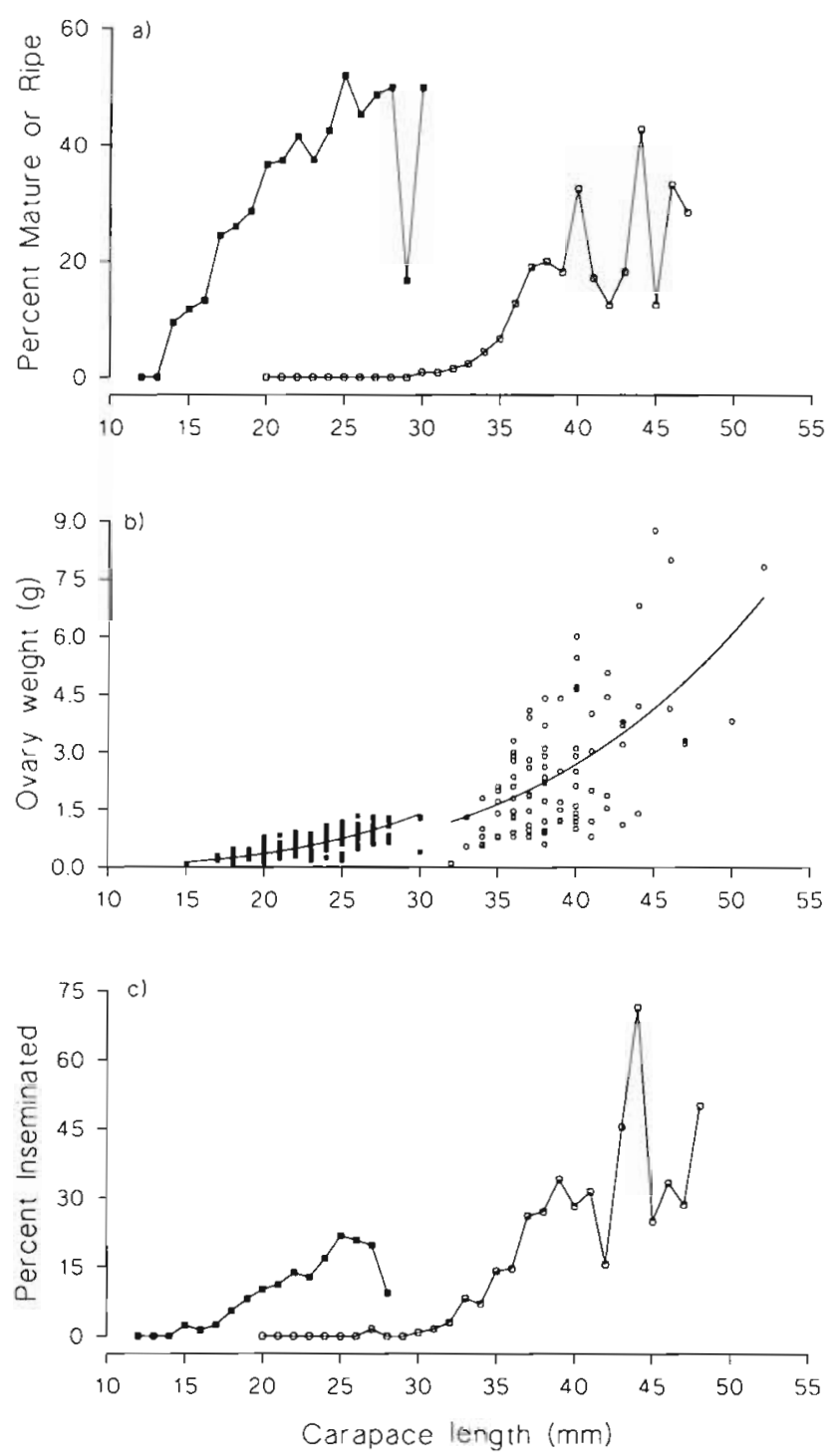

Fig. 2. Relationships for (a) percent of adult females classed as mature or ripe, (b) ovary weight in mature or ripe females. and (c) percent of females inseminated with a spermatophore, against carapace length. (-) Metapenaeus bennettae (ㅁ) Penaeus esculentus

Table 1. Regression coefficients ( $a$ and $b$ ) for carapace lengthovary weight relationships in mature and ripe Metapenaeus bennettae and Penaeus esculentus. n: number of observations; $r^{2}$ coefficient of determination; p: significance level

\begin{tabular}{|ccc|}
\hline Statistic & M. bennettae & P. esculentus \\
\hline$a$ & $1.020 \times 10^{-5}$ & $3.622 \times 10^{-6}$ \\
$b$ & 3.480 & 3.664 \\
$\mathrm{n}$ & 275 & 95 \\
$\mathrm{r}^{2}$ & 0.56 & 0.35 \\
$\mathrm{p}$ & $<0.001$ & $<0.001$ \\
\hline
\end{tabular}

meters and estimates of $a$ and $b$, obtained by iterative least-squares method, are given in Table 1.

\section{Insemination}

About $12 \%$ of adult female Metapenaeus bennettae had a spermatophore attached. The incidence of insemination in females smaller than $16 \mathrm{~mm}$ CL was negligible and increased in larger females to a maximum of $22 \%$ at $25 \mathrm{~mm} \mathrm{CL}$ (Fig. $2 \mathrm{c}$ ). About $20 \%$ of females larger than $25 \mathrm{~mm}$ CL were inseminated. Fourteen percent of adult Penaeus esculentus were inseminated. The smallest female inseminated was $27 \mathrm{~mm}$ CL. The incidence increased markedly over the size range 30 to $40 \mathrm{~mm} \mathrm{CL}$ (Fig. 2c). Of females larger than $40 \mathrm{~mm}$ CL, $31 \%$ were inseminated.

\section{Temporal variation in egg production}

\section{Metapenaeus bennettae}

Catch rates of adult female Metapenaeus bennettae were relatively high from September to April (spring to autumn) and low from May to August (late autumn to late winter) (Fig. 3a). Although there was considerable variation between years, some trends were apparent. Firstly, catch rates increased in September to November (spring) and February (summer) in both years. Secondly, catch rates peaked during February and March (late summer to early autumn) and declined sharply thereafter to May (late autumn) in both years.

Seasonal variation in the incidence of mature or ripe adult females was marked (Fig. 3b). The incidence was negligible from May to August (late autumn to late winter) and high from October to March (spring to early autumn in both years. In the first year, the mean incidence $( \pm \mathrm{SE})$ increased steadily from August (winter) to a peak in March $(59 \pm 5.4 \%$ ) (early autumn) while in the second year the increase from July to August (winter) was more rapid, resulting in an extended period of high incidence from October to January (spring to summer). A marked decline from March to June (early autumn to winter) occurred in both years.

Lunar monthly mean size $( \pm \mathrm{SE})$ of adult females (Fig. $3 \mathrm{c}$ ) ranged between $16.5 \pm 0.05$ and $22.1 \pm 0.06 \mathrm{~mm}$ CL. Mean size increased from September (spring) in both years to an annual maximum in January 1989 (summer) and in December and January 1990 (summer), and thereafter declined to May (late autumn). The most noticeable difference between years occurred in the June samples; mean size in June 1989 was $17.7 \pm$ $0.02 \mathrm{~mm} \mathrm{CL}$ and in June 1990 was $20.3 \pm 0.13 \mathrm{~mm}$ CL. 
广ั

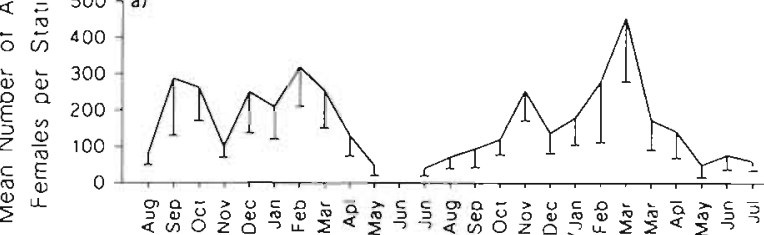

ఏ ᄃ
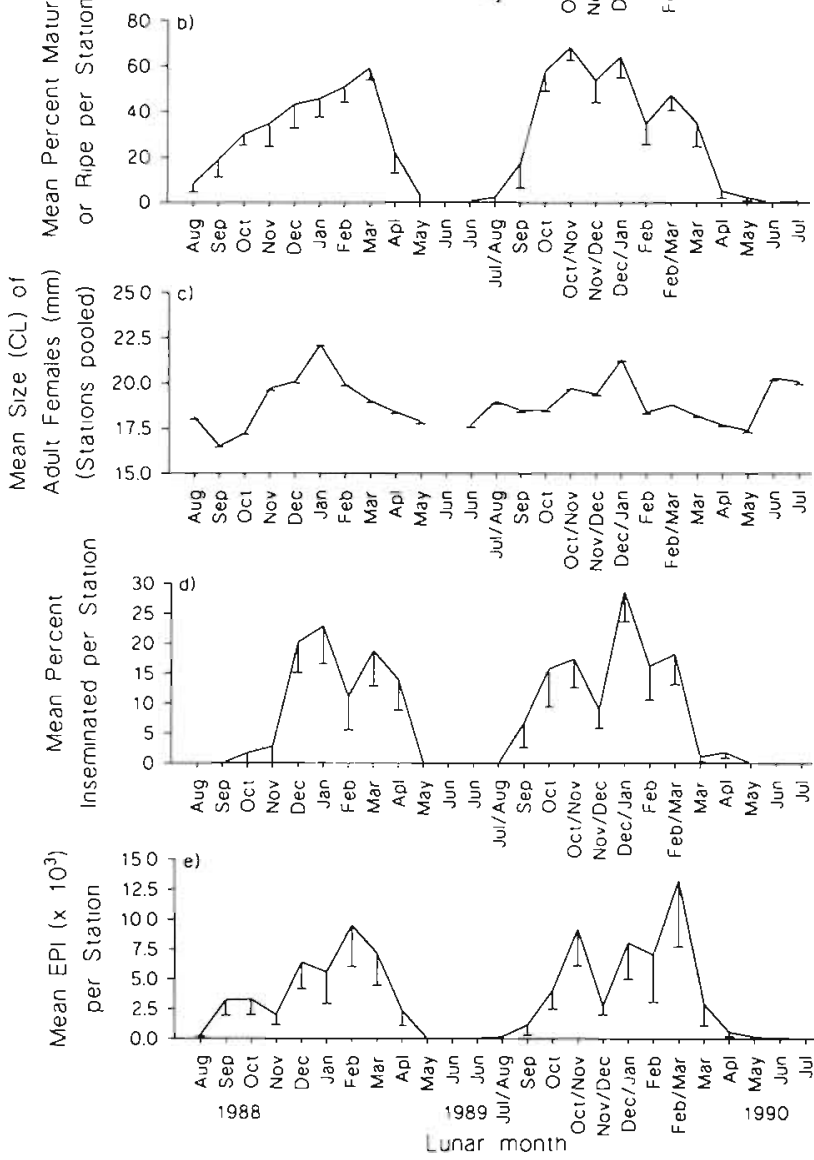

Fig. 3. Metapenaeus bennettae. Reproductive dynamics of prawns sampled from 9 stations over 25 consecutive lunar months: (a) mean number of adult females, (b) mean percentage of mature or ripe adult females, (c) mean size of adult females, (d) mean percentage of inseminated adult females, (e) mean egg production indices. Vertical lines represent $1 \mathrm{SE}$ below the mean

Trends in the incidence of inseminated adult Metapenaeus bennettae (Fig. 3d) were similar to those for the incidence of mature or ripe females. In the first year, relatively high incidences ( $>15 \%$ ) occurred from December to April (summer to autumn) while high incidences occurred slightly earlier, from October to February or March (spring to early autumn) in the second year. The incidence of insemination was consistently low $(<5 \%)$ from May to August (late autumn to late winter).

Lunar monthly mean EPIs for Metapenaeus bennettae (Fig. 3e) indicated egg production occurred over an extended period of 7 to 8 mo each year. Although there was a significant interaction between lunar months and years $(\mathrm{p}<0.05)$ affecting EPIs, a general trend was apparent in both years; egg production increased from August (winter), declined slightly in November and December (late spring and early summer), increased to an annual peak in February and March (late summer and early autumn) and declined thereafter to May (late autumn). Egg production from May to August (late autumn to late winter) was negligible

Egg production varied significantly $(p<0.001)$ among stations for Metapenaeus bennettae (see Fig. 5) and was several times higher at the northern stations (Stns 5 to 9) than at the southern stations (Stns 1 to 4 ). Maximum and minimum production occurred at Stns 8 (back-transformed adjusted mean EPI $=1337.8$ ) and 1 (back-transformed adjusted mean EPI $=10.6$ ), respectively. It was not possible to determine if there was a significant 3-way interaction (stations by lunar months by years) due to the lack of replication at each station on each trip. The fitted terms explained $87 \%$ of the variation observed in the EPIs.

\section{Penaeus esculentus}

There were 2 periods each year when the catch rate of adult females increased (Fig. 4a); a minor increase in September to November (spring) and a major increase in February to April (late summer to autumn) followed by a marked decline to July (winter). The timing and amplitude of the increases were similar in both years, indicating low seasonal and annual variation.

The seasonal onset of vitellogenesis was rapid and resulted in distinct annual peaks in the incidence of mature or ripe adult females at approximately the same time in both years (Fig. 4b). In the first year, the mean incidence $( \pm \mathrm{SE})$ increased from $0 \%$ in August (winter) to a peak of $57 \pm 17.1 \%$ in November (spring), while in the second year it increased from $0 \%$ in July and August (winter) to a peak of $75 \pm 11.2 \%$ in November and December (late spring and early summer). In both years the incidence declined rapidly from November to February (spring to late summer) and was negligible from February to August (late summer to winter).

Lunar monthly mean size ( \pm SE) of adult female Penaeus esculentus ranged between $32.3 \pm 3.09$ and $38.2 \pm 1.21 \mathrm{~mm} \mathrm{CL}$ (Fig. 4c). Minimum mean size of adult females occurred in February (late summer) each year. The main difference between years was that the marked decline from November and December 1989 to February 1990 and the increase from February to May 1990, were not apparent in the previous year.

Seasonal trends in the incidence of inseminated adult females (Fig. 4d) were similar to those for the 


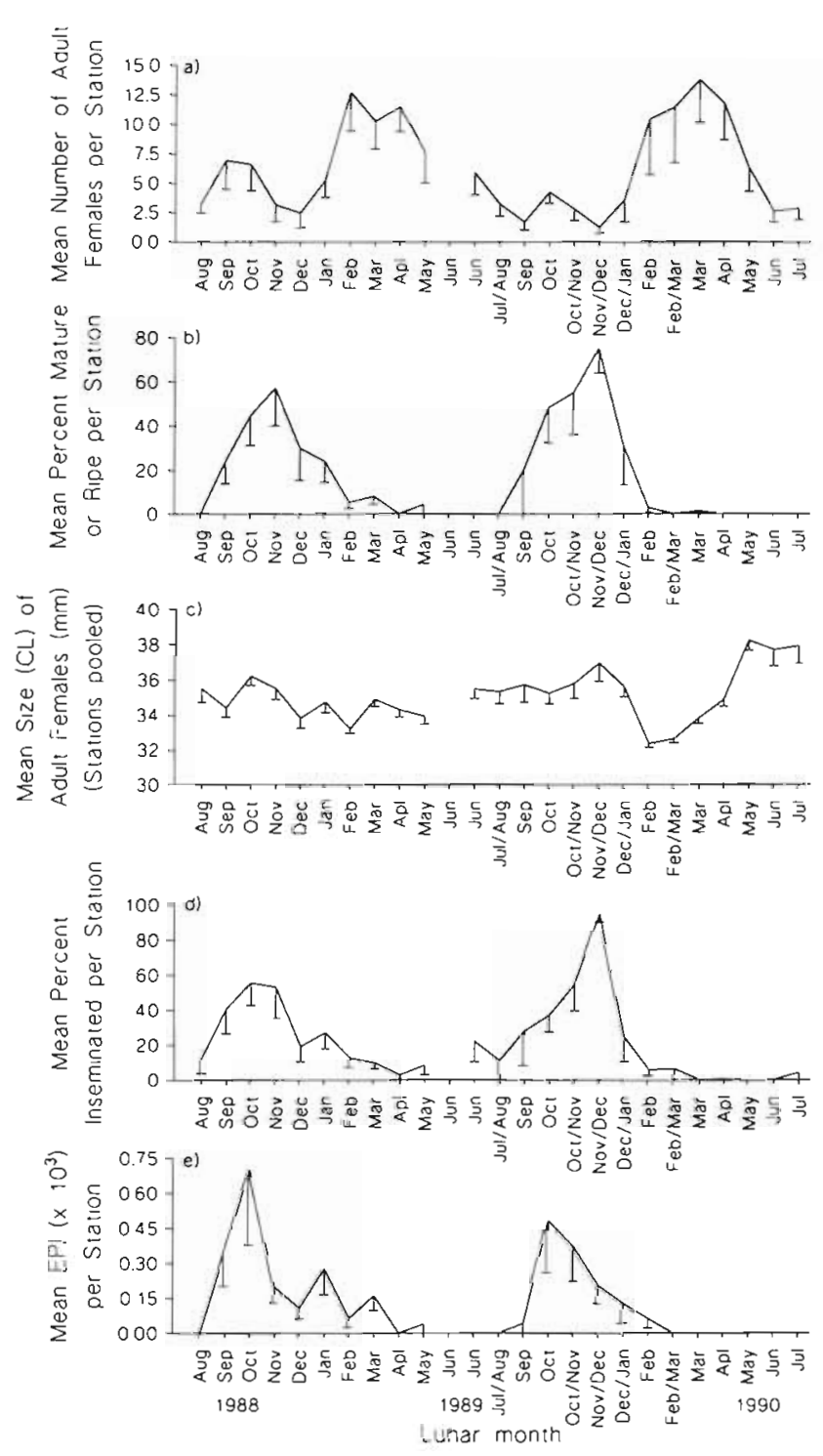

Fig. 4. Penaeus esculentus. Reproductive dynamics of prawns sampled from 9 stations over 25 consecutive lunar months: (a) mean number of adult females, (b) mean percentage of mature or ripe adult females, (c) mean size of adult females, (d) mean percentage of inseminated adult females, (e) mean egg production indices. Vertical lines represent 1 SE below the mean

incidence of mature or ripe females (Fig. $4 \mathrm{~b}$ ). In both years the incidence of insemination increased rapidly from August (winter) to a peak in October or November (spring), declined over the following 4 mo and remained relatively low $(<10 \%)$ from June to August (winter). Peak means differed between years; $55.6 \pm$ 12.90 and $95.0 \pm 5.00 \%$ for the first and second years, respectively.

Seasonal trends in egg production by Penaeus esculentus (Fig. $4 \mathrm{e}$ ) displayed little variation between years and were characterised by a rapid increase from no egg production (mean EPI $=0$ ) in August (winter) to a

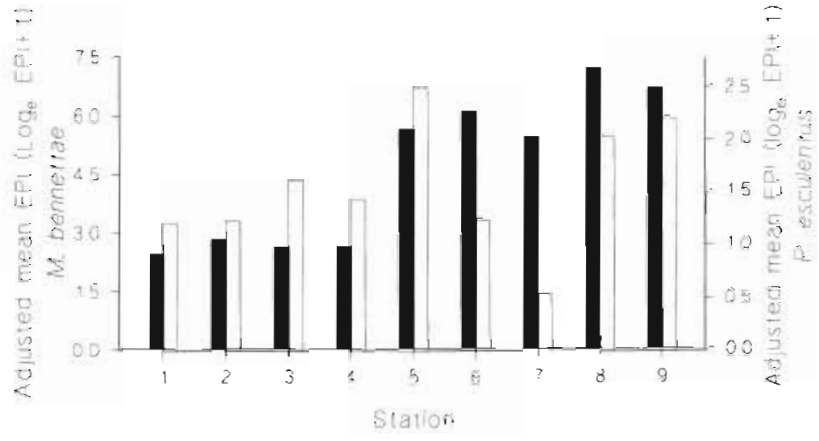

Fig. 5. Adjusted mean egg production indices (transformed) at 9 sampling stations in Moreton Bay. Solid bars: Metapenaeus bennettae; open bars: Penaeus esculentus

distinct peak in October (spring), The October peak was followed by a decline to March or April (autumn) in both years. Production from May to August (late autumn to winter) was negligible. ANOVA indicated egg production varied significantly among lunar months $(p<0.001)$ and years $(0.01<p<0.05)$. Backtransformed adjusted means were 5.8 and 2.9 for the first and second years, respectively.

Egg production by Penaeus esculentus was less varied among stations ( $p=0.07$ ) compared with Metapenaeus bennettae (Fig. 5). Highest production occurred at the 2 deepest stations (Stns 5 and 9; Fig 6a); backtransformed adjusted mean EPIs $=11.1$ and 8.0 , respectively. Lowest production occurred at the shallowest station (Stn 7); back-transformed adjusted mean EPI $=0.7$. The fitted terms explained $73 \%$ of the variation observed in EPIs for $P$. esculentus.

\section{Egg production and abiotic variables}

The mean depth $( \pm$ SE) of the stations (Fig. 6a) ranged from $6.2 \pm 0.13 \mathrm{~m}$ (Stn 7) to $16.8 \pm 0.48 \mathrm{~m}$ (Stn 5). Lunar monthly mean salinity $( \pm \mathrm{SE}$ ) ranged from $24.5 \pm 1.08$ to $35.0 \pm 0.00$ ppt. Salinity values generally increased from August (winter), remained high (>32 ppt) from October to December (spring to summer) and declined thereafter to an annual minimum (approximately $25 \mathrm{ppt}$ ) in March or April (autumn) (Fig. 6b). Water temperature exhibited a marked seasonal cyclic pattern (Fig. 6b); peaks and troughs lagged those of salinity by about 2 mo. Minimum lunar monthly mean temperatures were $17.6 \pm 0.20^{\circ} \mathrm{C}$ and $15.9 \pm 0.46^{\circ} \mathrm{C}$ for 1988 and 1989 , respectively and occurred in August (winter). Maximum temperatures were $27.2 \pm 0.44^{\circ} \mathrm{C}$ and $25.8 \pm 0.94^{\circ} \mathrm{C}$ in January (summer) 1989 and February (late summer) 1990, respectively. There was very little variation in temperature between stations during any single lunar month. Salin- 
ity varied between stations more than temperature, particularly during those months when salinity values were low [i.e. March to May (autumn); Fig. 6b]. Most of the variation occurred between the shallow northern stations (6 and 7) with salinities of $22 \mathrm{ppt}$ and the 2 centrally located stations ( 4 and 5 ) with salinities of approximately $29 \mathrm{ppt}$

Because the seasonal, cyclic patterns in temperature, salinity and EPIs generate autocorrelations, cautious interpretation of possible relationships between abiotic variables and EPIs is required. Although no causes or effects are implied, some correlations are noteworthy. Firstly, egg production by Metapenaeus bennettae was positively correlated with bottom temperature (Pearson correlation coefficient $r=0.30, n=216$, $\mathrm{p}<0.01)$ and uncorrelated with salinity. Secondly, and in contrast, egg production by $P$ enaeus esculentus was positively correlated $(\mathrm{r}=0.26, \mathrm{n}=216, P<0.01)$ with salinity and uncorrelated with temperature. The influence of the autocorrelations is reduced, and detection of any underlying correlations becomes more reliable, when short time periods are considered (although the number of observations is reduced) During periods of high egg production, EPIs were negatively correlated with salinity $(r=-0.21, n=$ $108, p<0.05$ ) for $M$ bennettae and positively correlated with depth $(\mathrm{r}=0.27, \mathrm{n}=81$, $\mathrm{p}<0.05$ ) for $P$. esculentus. No other significant correlations were detected. Thus, most egg production by $M$. bennettae occurred when bottom temperatures were high and at stations with relatively low salinity, while $P$. esculentus produced most of its eggs when salinity was high and at stations that were relatively deep.

\section{DISCUSSION}

\section{Comparison of the reproductive dynamics of Metapenaeus bennettae and Penaeus esculentus}

Both species exhibited marked seasonal patterns in abundance, vitellogenesis, insemination and egg production. The incidence of insemination was generally lower for Metapenaeus bennettae and during peak periods was about half that of Penaeus esculentus. Other studies (Crocos 1987a, b, Courtney \& Dredge 1988, Courtney et al. 1989; Potter et al. 1989) have also shown that the incidence of insemination is lower in
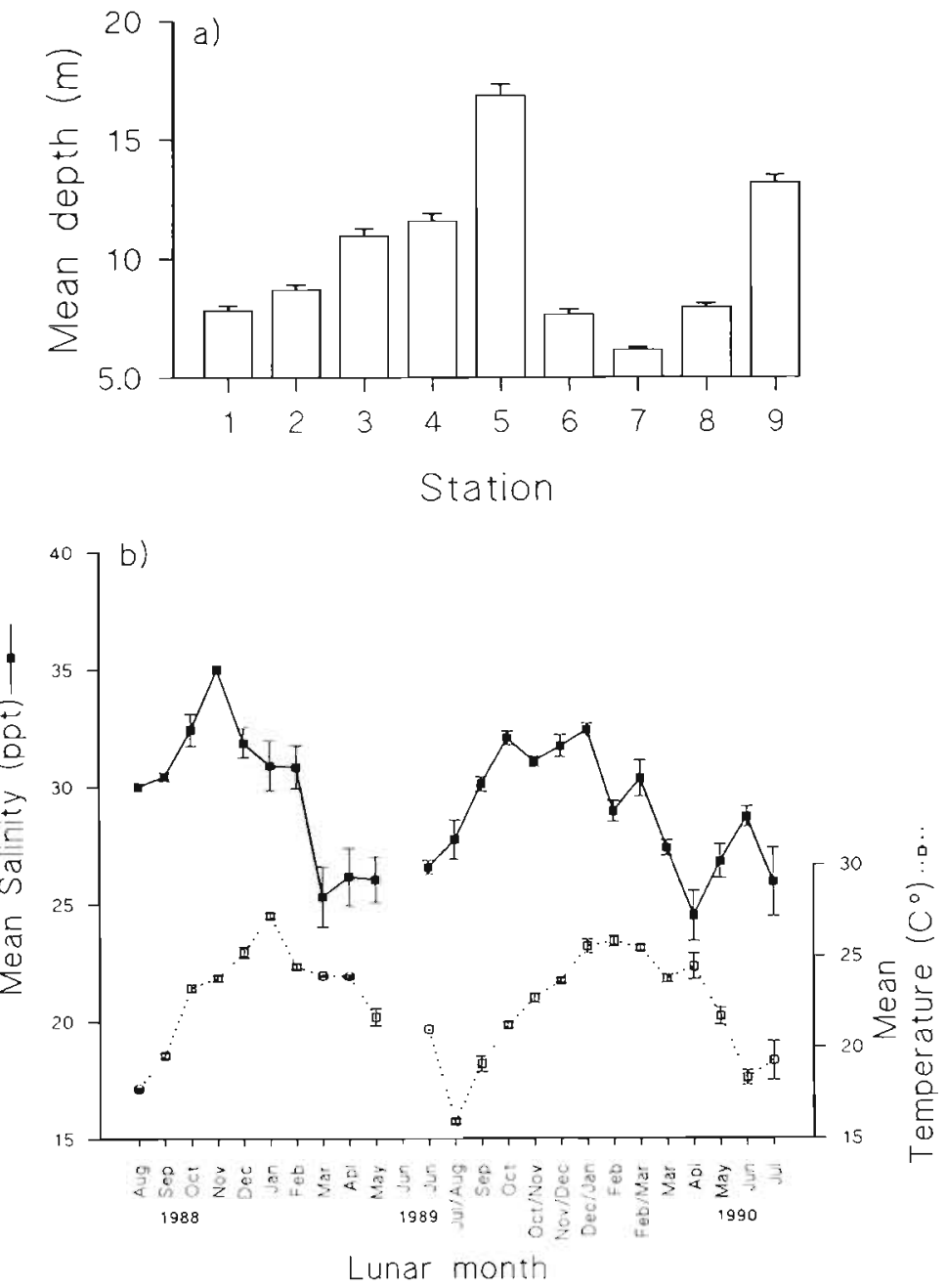

Fig. 6. Abiotic conditions at 9 sampling stations in Moreton Bay. (a) Mean depth of each of the 9 sampling stations, (b) mean bottom temperature and salinity values over 25 lunar monthly sampling trips. Vertical bars represent $1 \mathrm{SE}$ above the mean

open thelycum penaeids (such as those in the genus Metapenaeus) compared with closed thelycum penaeids (such those in the genus Penaeus). The reason for this is unknown, but is possibly due to the spermatophore being more readily dislodged in open thelycum penaeids.

Egg production by Metapenaeus bennettae was approximately 20 to 30 times higher (assuming both species produce similar numbers of eggs for a given weight of their mature ovaries) and occurred over a longer period each year, compared with Penaeus esculentus. This was due mainly to extended periods of high abundance (adult females were approximately 27 times more abundant for $M$. bennettae) coinciding with high incidences of mature or ripe females (incidence of mature or ripe adult females was approximately 4 times higher for $M$. bennettae). Egg produc- 
tion from May to August (later autumn to winter) was negligible for both species.

The spatial distribution of egg production differed between species. Metapenaeus bennettae produced most eggs at the northern stations and in areas with low salinity. Egg production by Penaeus esculentus varied marginally among stations but was positively correlated with depth. The negative correlation between egg production and salinity for $M$. bennettae is consistent with the general dependence of Metapenaeus species on an estuarine phase (Kutkuhn 1966) and with Kirkegaard's (1975) speculation that adult females must place larvae in their most suitable zones. It is also consistent with the preference post-larval $M$. bennettae display for habitats with a freshwater influence (Young \& Carpenter 1977).

Peaks in egg production by Penaeus esculentus occurred when the incidence of mature or ripe females was high and abundance of adult females was low. In contrast, peak periods of egg production by Metapenaeus bennettae occurred when both female abundance and the incidence of mature or ripe females were high. This suggests that $P$. esculentus is more likely to experience recruitment overfishing in Moreton Bay than $M$. bennettae because it produces significantly fewer eggs which are the result of a small population of adult females spawning over a brief period.

Furthermore, the selectivity of the mesh used by fishers in Moreton Bay is more likely to contribute to recruitment overfishing of Penaeus esculentus than Metapenaeus bennettae. This is because $M$. bennettae recruits to the fishing grounds at the relatively small size of approximately $14 \mathrm{~mm} \mathrm{CL}$ (Courtney et al 1995a) and is capable of reproducing at sizes smaller than those retained in the codends (selectivity of $M$. bennettae at $14 \mathrm{~mm} \mathrm{CL}$ is $<10 \%$; Courtney et al. 1991). In contrast, $P$. esculentus recruits at the relatively large size of approximately $27 \mathrm{~mm}$ CL which is almost fully retained (selectivity $>90 \%$; Courtney et al. 1991). Thus, retention of spawners by the fleet is much higher for $P$. esculentus than $M$. bennettae.

\section{Comparisons with other studies}

\section{Metapenaeus bennettae}

Metapenaeus bennettae is a small species restricted to shallow, estuarine areas on Australia's east coast. The early work of Morris \& Bennett (1952) demonstrated that it was capable of maturing and spawning in periodically enclosed coastal lakes of New South Wales $\left(33^{\circ}\right.$ to $\left.35^{\circ} \mathrm{S}\right)$. They also found the incidence of females with visibly developed ovaries was high from November to March, similar to the seasonal trends obtained in the present study (October to March; Fig. 3b). Studies by Dall (1958) and Hyland (1987) have shown that extremely few females mature in rivers, and that they prefer to migrate downstream to open waters to mate and spawn. The current study has confirmed that $M$. bennettae produces most of its eggs outside of river systems, but within areas that have a freshwater influence.

The effective spawning period (as defined by Crocos 1995) for stock renewal was difficult to determine for Metapenaeus bennettae in Moreton Bay. Both egg production and recruitment to the fishing grounds (Courtney et al. 1995a) extended over several months and varied between years. Although mean EPIs reached a maximum in February and March each year, recruitment in the months following (i.e. May to August) was negligible. Thus, the period of highest egg production was not the most important for stock renewal. The most consistent recruitment period was from February and March which was likely to result from egg production in October to November (spring).

\section{Penaeus esculentus}

The reproductive dynamics of Penaeus esculentus have been studied more extensively than those of Metapenaeus bennettae. O'Connor (1979) examined temporal variation in the gonad index of a population located near Low Islets $\left(16^{\circ} \mathrm{S}\right.$, about $1200 \mathrm{~km}$ north of Moreton Bay). His results differed markedly from those of the present study, in that the index tended to peak between February and May. This may have been partly due to the relatively restricted sampling area influencing the size range of individuals sampled, as noted by O'Connor (1979). Keating et al. (1990) developed a population fecundity index similar to that used in the present study to describe spawning patterns of $P$. esculentus in Torres Strait, northeast Australia $\left(10^{\circ} \mathrm{S}\right)$. They found that egg production occurred throughout the year. In the Exmouth Gulf fishery, Western Australia $\left(22^{\circ} \mathrm{S}\right)$. White (1975) found the major spawning period for $P$. esculentus was October to December, based on a combination of histological and macroscopic methods.

Several authors have examined the reproductive dynamics of Penaeus esculentus in the Gulf of Carpentaria $\left(11^{\circ}\right.$ to $\left.17^{\circ} \mathrm{S}\right)$. Robertson et al. (1985) concluded that highest annual spawning potential in the southeastern Gulf occurred from July to October, based upon the incidence of females with visible ovaries. Buckworth (1985) concluded that spawning in the southwestern Gulf was protracted, but particularly high in July and October. Crocos (1987b) utilised a population fecundity index to describe the temporal 
and spatial patterns in egg production for $P$. esculentus in the northwestern Gulf. Egg production was protracted and displayed considerable interannual variation. Crocos (1987b) concluded that high egg production in late winter to early spring (July to October) was the most effective spawning period because it accounted for the November to March recruitment of sub-adults. Egg production outside this period did not contribute markedly to stock renewal.

The spring peak in egg production determined for Penaeus esculentus in the present study was generally consistent with results on the seasonal abundance of post-larvae (Young \& Carpenter 1977) and juveniles (O'Brien 1994) in nursery areas in the bay. It was also consistent with the timing (February to May) and size $(27 \mathrm{~mm} \mathrm{CL}$ ) at recruitment to the fishery (Courtney et al. 1995a). For example, an individual spawned in midOctober is likely to experience a typical pelagic, penaeid larval phase of approximately $3 \mathrm{wk}$ (Dall et al. 1990b) and become epibenthic at approximately $2 \mathrm{~mm}$ CL (Young 1978). Given an average instantaneous growth rate for juvenile $P$. esculentus of approximately $1.2 \mathrm{~mm} \mathrm{CL} \mathrm{wk}^{-1}$ (Loneragan et al. 1994, O'Brien 1994), by $24 \mathrm{wk}$ of age (the last week of March), the prawn will be $27.2 \mathrm{~mm}$ CL. Thus, the effective spawning period for $P$. esculentus in Moreton Bay is October to November (spring).

\section{Latitudinal variation in Penaeus esculentus}

The study revealed a number of differences in the reproductive dynamics of Penaeus esculentus between populations in Moreton Bay $\left(27^{\circ} 15^{\prime} \mathrm{S}\right)$ and those at lower latitudes $\left(10\right.$ to $\left.17^{\circ} \mathrm{S}\right)$. These differences provide an insight into how egg production varies with latitude and have implications for assessing the likelihood of recruitment overfishing stocks of $P$. esculentus, and possibly other penaeids

Firstly, the size at which female Penaeus esculentus first mature in Moreton Bay is larger than that observed at lower latitudes. In the present study none of the females smaller than $30 \mathrm{~mm}$ CL were mature and $<1 \%$ of $30 \mathrm{~mm} \mathrm{CL}$ females were mature. In contrast, studies by Robertson et al. (1985) in the southeastern Gulf of Carpentaria $\left(17^{\circ} \mathrm{S}\right)$ and Buckworth (1985) in the western Gulf ( $\left.14^{\circ} \mathrm{S}\right)$ have shown that maturation commenced at about $25 \mathrm{~mm}$ CL and that about $30 \%$ of $30 \mathrm{~mm}$ CL females were mature. Similar results were presented by Keating et al. (1990) in Torres Strait $\left(10^{\circ} \mathrm{S}\right)$. Crocos (1987b) concluded from ovarian histological examination that the minimum size at maturity was $25 \mathrm{~mm} \mathrm{CL}$ and that about $35 \%$ of $30 \mathrm{~mm} \mathrm{CL}$ females were mature in the northwestern Gulf $\left(13^{\circ} 30^{\prime} \mathrm{S}\right)$. Also, the overall incidence of mature females was lower in Moreton Bay ( $9.4 \%$ ) compared with results of studies undertaken in the Gulf. In the present study, approximately $20 \%$ of females $>35 \mathrm{~mm}$ CL were mature while in the Gulf about 70 to $80 \%$ of females > $35 \mathrm{~mm} \mathrm{CL}$ were mature (Buckworth 1985 , Robertson et al. 1985, Crocos 1987b).

Secondly, the seasonal onset of maturation in adult female Penaeus esculentus in Moreton Bay was rapid and the incidence of mature or ripe females restricted to a few months (Fig. 4b). In the Gulf of Carpentaria mature females were relatively common (>20\%) for most months of the year and never completely absent from samples (Buckworth 1985, Robertson et al. 1985, Crocos 1987b). Thirdly, the incidence of insemination was much lower compared with results from the Gulf of Carpentaria (Crocos 1987b). In the present study, $<1 \%$ of $30 \mathrm{~mm}$ CL females and about $26 \%$ of females $>35 \mathrm{~mm}$ CL were inseminated, whereas approximately $35 \%$ of $30 \mathrm{~mm} \mathrm{CL}$ females and $75 \%$ of females $>35 \mathrm{~mm}$ CL were inseminated in the Gulf.

These differences indicate that as latitude increases, the overall proportion of adult females in the population that contribute to egg production (i.e. those classed as mature or ripe) declines, the size class range of the adult females producing eggs narrows (because maturation commences at a larger size), and the annual period of egg production shortens. The lower overall incidence of insemination may also result in relatively few eggs being fertilised after spawning. This variation indicates that spawning stocks of Penaeus esculentus are likely to become more vulnerable to overfishing with increasing latitude. Such a trend probably applies to other penaeid prawn species as well

Acknowledgements. This study was funded by the Queensland Fisheries Management Authority and the Queensland Department of Primary Industries. We thank skippers Dave Trama, Jack Kelly, the crews of the RV 'Bar-ea-mul', 'Sea Wanderer' and 'Deep Tempest' and Messrs Adam Butcher and Darren Smallwood for assisting with the field and laboratory work. Comments and suggestions by Drs lan Brown and John Kirkwood and Mr Mike Dredge are gratefully acknowledged

\section{LITERATURE CITED}

Anderson SL, Clark WH, Chang ES (1985) Multiple spawning and molt synchrony in a free spawning shrimp (Sicyonia ingentis: Penaeoidea). Biol Bull Mar Biol Lab, Woods Hole 168:3773-94

Buckworth RC (1985) Preliminary results of a study of commercial catches, spawning and recruitment of Penaeus esculentus in the western Gulf of Carpentaria. In: Rothlisberg PC, Hill BJ, Staples DJ (eds) Second Australian National Prawn Seminar. NPS2, Cleveland, Queensland, p 213-220

Coles RG, Lee Long WJ, Squire BA, Squire LC, Bibby JM (1987) Distribution of seagrasses and associated juvenile 
commercial penaeid prawns in north-eastern Queensland waters. Aust J Mar Freshwat Res 38:103-119

Courtney AJ, Dredge MCL (1988) Female reproductuve biology and spawning perlodicity of two species of king prawns, Penaeus longistylus Kubo and Penaeus latisulcatus Kishinouye, from Queensland's east coast fishery. Aust J Mar Freshwat Res 39(6):729-741

Courtney AJ, Dredge MCL, Masel JM (1989) Reproductive biology and spawning periodicity of endeavour shrimps Metapenaeus endeavouri (Schmitt, 1926) and Metapenaeus ensis (de Haan, 1850) from a central Queensland (Australia) fishery. Asian J Fish Sci 3:133-147

Courtney AJ, Masel JM, Die DJ (1991) An assessment of recently introduced seasonal prawn trawl closures in Moreton Bay, Queensland. Queensland Department of Primary Industries Information Series No. Q191037

Courtney AJ, Masel JM, Die DJ (1995a) Temporal and spatial patterns in recruitment of three penaeid prawns in Moreton Bay, Queensland, Australia. Estuar Coast Shelf Sci 41. $377-392$

Courtney AJ, Montgomery SS, Die DJ, Andrew NL, Cosgrove MG, Blount C (1995b) Maturation in the female eastern king prawn, Penaeus plebejus, from coastal waters of Eastern Australia and considerations for quantifying egg production in penaeid prawn populations. Mar Biol 122: $547-556$

Crocos PJ (1987a) Reproductive dynamics of the grooved tiger prawn, Penaeus semisulcatus, in the north-western Gulf of Carpentaria, Australia. Aust J Mar Freshwat Res 38:79-90

Crocos PJ (1987b) Reproductuve dynamics of the tiger prawn, penaeus esculentus, and a comparison with $P$. semisulcatus, in the north-western Gulf of Carpentaria, Australia. Aust J Mar Freshwat Res 38:91-102

Crocos PJ (1991) Reproductive dynamics of three species of Penaeidae in tropical Australia, and the role of reproductive studies in fisheries management. In: Wenner A, Kuns A (eds) Crustacean issues 7: crustacean egg production. Balkema, Rotterdam, p 317-331

Crocos P (1995) Characterising the spawning population of grooved tiger prawns. In: Courtney $A J$, Cosgrove MG (eds) Proceedings of the workshop on spawning stockrecruitment relationships (SRRs) in Australian crustacean fisheries. Joondoburri Conference Centre 1-3 June, 1994 Queensland Department of Primary Industres, p 84-85

Dall W (1958) Observations on the biology of the greentail prawn, Metapenaeus mastersij (Haswell) (Crustacea Decapoda: Penaeidae). Aust J Mar Freshwat Res 9:111-34

Dall W (1985) A review of penaeid prawn biological research in Australia. In: Rothlısberg PC. Hill BJ, Staples DJ (eds) Second Australian National Prawn Seminar. NPS2, Cleveland, Queensland, p 11-21.

Dall W, Hill BJ, Rothlisberg PC, Staples DJ (1990a) Chapter 7 Reproduction. In: Dall W. Hill BJ, Rothlisberg PC, Staples DJ (eds) Advances in marine biology, Vol 27. The biology of the Penaeidae. Academic Press, London, p 251-281

Dall. W, Hill BJ, Rothlisberg PC, Staples DJ (1990b) Chapter 8. Life histories. In: Dall W, Hill BJ, Rothlisberg PC, Staples DJ (eds) Advances in marine biology, Vol 27. The biology of the Penaeidae. Academic Press, London, p 283-314

El Hady HA, Abdel Razek FA, Ezzat A (1990) Reproduction of Penaeus semisulcatus de Haan in Dammam Water (Arabia Gulf), Kingdom of Saudi Arabia. Arch Hydrobiol 118(2): $241-251$

Gab-Alla AAFA, Hartnoll RG, Ghobashy AF, Mohammed SZ (1990) Biology of penaeid prawns in the Suez Canal lakes. Mar Biol 107:417-426
Garcia $S$ (1983) The stock-recruitment relationship in shrumps: reality or artefacts and misinterpretations? Oceanogr Trop 18(1):25-48

Glaister JP, Lau T, McDonall VC (1987) Growth and migration of tagged eastern Australian king prawns, Penaeus plebejus Hess. Aust J Mar Freshwat Res 38:225-242

Glaister JP, Montgomery SS, MCDonall VC (1990) Yield-perrecruit analysis of eastern king prawns, Penaeus plebejus Hess, in eastern Australia. Aust J Mar Freshwat Res 41 $175-197$

Gordon GNG, Andrew NL, Montgomery SS (1995) Deterministic compartmental model for the eastern king prawn (Penaeus plebejus) fishery in New South Wales. Mar Freshwat Res 46:793-807

Gracia A (1991) Spawming stock-recruitment relationships of white shrimp in the southwestern Gulf of Mexico. Trans Am Fish Soc 120:519-527

Gracia A (1996) White shrimp (Penaeus setiferus) recruitment overfishing. Mar Freshwat Res 47:59-65

Grey DL, Dall W, Baker A (1983) A guide to the Australian penaeid prawns. Department of Primary Production, Northern Territory Government, Darwin

Hyland SJ (1987) An investigation of the nektobenthic organisms in Logan River and Moreton Bay, Queensland with an emphasis on penaeid prawn. MSc thesi:. University of Queensland, Brisbane

Keating JA. Watson RA, Sterling DJ (1990) Reproductive biology of Penaeus esculentus (Haswell, 1879) and Metapenaeus endeavoun (Schmitt, 1926) in Torres Strait. In: Mellors JE (ed) Torres Strait Prawn Project: a review of research 1986-88. Queensland Department of Primary Industries Information Series QI90018. Queensland Department of Primary Industries, p 51-61

Kirkegaard I (1975) Observations of penaeid larvae around Australia. In: Young PC (ed) First Australian National Prawn Seminar. Australian Government Publishing Service, Canberra, p 54-59

Kirkwood GP, Somers IF (1984) Growth of two species of tiger prawn, Penaeus esculentus and $P$. semisulcatus, in the western Gulf of Carpentaria. Aust J Mar Freshwat Res 35 $707-712$

Kutkuhn JH (1966) Dynamics of a penaeid shrimp population and management implication. Fish Bull 65(2):313-318

Loneragan NR, Kenyon RA, Haywood MDE, Staples DJ (1994) Population dynamics of juvenile tiger prawns (Penaeus esculentus and Penaeus semisulcatus) in seagrass habitats of the western Ciulf of Carpentaria, Australia. Mar Biol 119(1):133-143

Lucas C (1974) Preliminary estimates of stocks of the king prawn, Penaeus plebejus, in South-East Queensland. Aust J Mar Freshwat Res 25:35-47

Mellors JE (1990) Torres Strait Prawn Project: a review of research 1986-88. Queensland Department of Primary Industries Information Series Q190018, p 1-138

Montgomery SS (1990) Movements of juvenile eastern king prawns, Penaeus plebejus, and identification of stocks along the east coast of Australia. Fish Res 9:189-208

Morris MC, Bennett I (1952) The life history of a penaeid prawn (Metapenaeus) breeding in a coastal lake (Tuggerah, New South Wales). Proc Linnean Soc NSW 76:164-182

Neal RA (1975) The Gulf of Mexico research and fishery on penaeid prawns. In: Young PC (ed) First Australian National Prawn Seminar. Australian Government Publishing Service, Canberra, p $1-8$

O'Brien C (1994) Population dynamics of juvenile tiger prawns Penaeus esculentus in south Queensland, Australia. Mar Ecol Prog Ser 104:247--256 
O'Connor C (1979) Reproductive periodicity of a Penaeus esculentus population near Low lslets, Queensland, Australia. Aquaculture 16:153-162

Penn JW, Caputi N (1985) Stock-recruitment relationships for the tiger prawn, Penzeus esculentus, fishery in Exmouth Gulf, Western Australia, and therr implications for management. In: Rothlisberg PC, Hill BJ, Staples DJ (eds) Second Australian National Prawn Seminar NPS2. Cleveland, Queensland, p 165-173

Penn JW, Caputi N (1986) Spawnıng stock-recruitment relationships and environmental influences on the tiger prawn (Penaeus esculentus) fishery in Exmouth Gulf, Western Australia. Aust J Mar Freshwat Res 37:491 505

Penn JW, Caputi N, Hall NG (1995) Stock-recruitment relationships for the tiger prawn (Penaeus esculentus) stocks in Western Australia. ICES Mar Sci Symp 199:320-333

Penn JW, Hall NG, Caputi N (1989) Resource assessment and management perspectives of the penaeid prawn fisheries of Western Australia. In: Caddy JF (ed) Marıne invertebrate fisheries. their assessment and management. Wiley and Sons, Brisbane, p 115-140

Potter IC, Baronie FM, Manning RJG, Loneragan NR (1989) Reproductive biology and growth of the western school prawn, Metapenaeus dalli, in a large Western Australıan estuary. Aust J Mar Freshwat Res 40:327-340

Potter IC, Manning RJG, Loneragan NR (1991) Size, movements, distribution and gonadal stage of the western king prawn (Penaeus latisulcatus) in a temperate estuary and local marine waters. J Zool Soc Lond 223:419-445

Potter MA (1975) Movements of the eastern king prawn (Penaeus plebejus) in southern Queensland waters. In: Young PC (ed) First Australian National Prawn Seminar. Australian Government Publishing Service, Canberra, p 10-17

Robertson JWA, Coles RG, Goeden GB (1985) Distrubution patterns of commercial prawns and reproduction of Penaeus esculentus around the Wellesley Islands in the southeastern. Gulf of Carpentaria. In: Rothlisberg PC, Hill

This article was presented by A. J. Underwood (Senior Editorial Advisor), Sydney, NSW, Australia
BJ. Staples DJ (eds) Second Australian National Prawn Seminar. NPS2, Cleveland, Queensland, p 71-75

Ruello NV (1975a) An historical review and annotated bibliography of prawns and the prawning industry in Australia. In: Young PC (ed) First Australian National Prawn Seminar Australian Government Publishing Service, Canberra, p 305-341

Ruello NV (1975b) Geographical distrubution, growth and breeding migration of the eastern Australian king prawn Penaeus plebejus Hess. Aust J Mar Freshwat Res 26: 34.3-354

Shlagman A, Lewinsohn C. Tom M (1986) Aspects of the reproductive activity of Penaeus semisulcatus de Haan along the southeastern coast of the Mediterranean. Mar Ecol 7(1):15-22

Staples DJ, Vance DJ, Heales DS (1985) Habitat requirements of juvenile penaeid prawns and their relationship to offshore fisheries. In: Rothlisberg PC, Hill BJ. Staples DJ (eds) Second Australıan National Prawn Seminar NPS2, Cleveland, Queensland, p 47-54

Tuma DJ (1967) A description of the development of primary and secondary sexual characteristics in the banana prawn, Penaeus merguiensis de Man (Crustacea: Decapoda: Penaeinae). Aust J Mar Freshwat Res 18:73-88

White TF StC (1975) Population dynamics of the tiger prawn Penaeus esculentus (Haswell, 1879) (Crustacea: Penaeldae) in the Exmouth Gulf prawn fishery, and implications for the management of the fishery. PhD thesis, University of Western Australia, Nedlands

Yano I (1988) Oocyte development in the kuruma prawn Penaeus japonicus. Mar Biol 99:547-553

Young PC (1978) Moreton Bay. Queensland. A nursery area tor Juvenile penaeid prawns. Aust J Mar Freshwat Res 29: $55-75$

Young PC, Carpenter SM (1977) Recruitment of postlarval penaeld prawns to nursery areas in Moreton Bay, Queensland. Aust J Mar Freshwat Res 28:745-773

Manuscript furst recelved: June 23, 1996

Revised version accepted: September 17, 1996 